\title{
REQUISIÇÃO DE IMÓVEIS DE PARTICULARES PELA JUSTIÇA ELEITORAL
}

\section{Edgard Fernando Barbosa}

Especialista em Direito Processual, Direito Processual Civil e Direito Civil pelo IBEJ - Instituto Brasileiro de Estudos Jurídicos, Mestrando em Direito pela UFPR, Juiz de Direito no Paraná.

\begin{abstract}
"A importância prioritária da efetividade eleitoral na vida da nação ressalta do teleologismo que se faz evidente em toda a legislação eleitoral." (ELCIAS FERREIRA DA COSTA) ${ }^{1}$
\end{abstract}

\begin{abstract}
SUMÁRIO: 1 O processo eleitoral brasileiro e a definição dos locais de votação; 2 A legitimidade da justiça eleitoral para requisitar imóveis de particulares; 3 A requisição e as demais formas de intervenção do Estado no domínio privado; 4 Requisição de bens pela justiça eleitoral: um direito constitucionalmente assegurado; $5 \mathrm{O}$ confronto entre o direito estatal de requisitar e o direito de propriedade, ambos assegurados constitucionalmente; Conclusão; Referências bibliográficas.
\end{abstract}

RESUMO: Propõe-se, nas linhas que se seguirão, sustentar a possibilidade jurídica da requisição de imóveis de particulares pela justiça eleitoral, notadamente em face das teses que poderão ser levantadas em sentido contrário, como a alegação de que o manejo daquele instituto ofenderia ao direito constitucional de propriedade e dimanaria de norma inconstitucional, qual seja, o art. $135, \S \S 2^{\circ}$ e $3^{\circ}$, do Código Eleitoral, que não teria sido recepcionado pela nova Carta, ou ainda o argumento de que a requisição, como forma de intervenção estatal no domínio privado, somente seria possível mediante a correspondente compensação financeira, nos moldes da desapropriação, da ocupação temporária e da servidão administrativa, ou desde que previamente ajustada, como na locação. Vamos ao debate.

\section{O PROCESSO ELEITORAL BRASILEIRO E A DEFINIÇÃO DOS LOCAIS DE VOTAÇÃO}

O processo eleitoral decorre do modelo político historicamente adotado em nosso País, insculpido na vigente Carta Constitucional nos seguintes termos:

"Art. $1^{\circ}$ A República Federativa do Brasil, formada pela união indissolúvel dos Estados e Municípios e do Distrito Federal, constitui-se em Estado Democrático de Direito (...).

Parágrafo único. Todo o poder emana do povo, que o exerce por meio de representantes eleitos ou diretamente, nos termos desta Constituição."

Segundo o eminente Professor PAULO AGUIAR DE OLIVEIRA, ${ }^{2}$ da Universidade Católica de Minas Gerais, a justiça eleitoral brasileira foi criada em 1932,

1 Compêndio de direito eleitoral. 1. ed. São Paulo: Sugestões Literárias, 1978, p. 129.

2 Responsabilidade do Estado por atos da justiça eleitoral. Revista de Direito Público, São Paulo: Revista dos Tribunais, v. 20, n. 83, p. 62, jul./set. 1987. 
tendo a Constituição Federal de 1934 a incluído entre os órgãos do Poder Judiciário, ao qual ficou incumbido todo o processo eleitoral, do alistamento dos eleitores à diplomação dos eleitos.

Ainda segundo a lição do nominado mestre mineiro, a justiça eleitoral é órgão da justiça federal, sendo porém exercida pela justiça dos Estados, conquanto esta dispõe de estrutura organizacional em todos os rincões do território nacional, o que não ocorre com aqueloutra. ${ }^{3}$

Como se sabe, a estruturação da justiça eleitoral é dada pelos arts. 118 usque 121 da Constituição Federal de 1988, que estabelece como seus órgãos o Tribunal Superior Eleitoral, os tribunais regionais eleitorais, os juízes eleitorais e as juntas eleitorais.

Consoante disposto no art. 22, incisos I e III, ${ }^{4}$ da Constituição Federal, compete privativamente à União editar normas relativas a direito eleitoral e requisições civis e militares, sendo certo que a principal fonte infra-constitucional do direito eleitoral brasileiro é a Lei $\mathrm{n}^{\circ} 4.737$, de 15.07.1965, que corresponde ao vigente Código Eleitoral e que, na ausência de outra norma supletiva, corresponde à legislação complementar reclamada pelo caput do art. 121 da citada Carta Constitucional. ${ }^{5}$

Referindo-se ao processo eleitoral brasileiro, JOEL J. CÂNDIDO 6 assim se pronuncia:

"A primeira grande fase do processo eleitoral é a fase preparatória, ou a preparação eleitoral. Como já foi dito, ela se inicia com as convenções partidárias, podendo, ou não, englobar o alistamento como um de seus momentos (CE, art. 67). Passa, a seguir, pelo registro dos candidatos e pela propaganda eleitoral e vem terminar em seu ponto de maior destaque e relevo, que é o das medidas preliminares à votação e à apuração. Enquanto que o alistamento eleitoral tem como protagonista o povo, que quer se tornar eleitor, a partir dos dezesseis anos, o registro dos candidatos e a propaganda eleitoral envolvem, predominantemente os partidos políticos, as medidas preliminares à votação e à apuração movimentam, basicamente, os órgãos da justiça eleitoral."

Assim, e ainda para JOEL J. CÂNDIDO: ${ }^{7}$

3 Op. cit.

4 Constituição Federal:

"Art. 22. Compete privativamente à União legislar sobre:

I - direito civil, comercial, penal, processual, eleitoral, agrário, marítimo, aeronáutico, espacial e do trabalho;

(...)

III - requisições civis e militares, em caso de iminente perigo e em tempo de guerra.”

5 Constituição Federal:

“Art. 121. Lei complementar disporá sobre a organização e competência dos tribunais, dos juízes de direito e das juntas eleitorais."

6 Direito eleitoral brasileiro. 8. ed. Bauru: EDIPRO, 2000, p. 171.

7 Op. cit., loc. cit. 
“(...) neste quarto e último momento da primeira grande fase do processo eleitoral, os órgãos da justiça eleitoral devem se preocupar, fundamentalmente, com a composição e a organização das mesas receptoras de votos; com a escolha e nomeação dos membros das juntas eleitorais e com a designação e treinamento dos mesários, escrutinadores e auxiliares dessas mesas e juntas. Seja qual for a eleição que se esteja preparando, essas medidas serão sempre de responsabilidade dos tribunais regionais eleitorais e das zonas eleitorais - estas através de seus juízes - (...)."

A questão trazida para debate diz respeito especificamente à definição dos locais da votação, que é deste modo regulada no Código Eleitoral:

"Art. 35. Compete aos juízes:

(...)

XIII - designar, até 60 (sessenta) dias antes das eleições, os locais das seções;

(...)

Art. 135. Funcionarão as mesas receptoras nos lugares designados pelos juízes eleitorais 60 (sessenta) dias antes da eleição, publicando-se a designação.

$\S 1^{\circ}$ A publicação deverá conter a seção com a numeração ordinal e local em que deverá funcionar, com a indicação da rua, número e qualquer outro elemento que facilite a localização pelo eleitor.

$\S 2^{\circ}$ Dar-se-á preferência aos edifícios públicos, recorrendo-se aos particulares se faltarem aqueles em número e condições adequadas.

$\S 3^{\circ}$ A propriedade particular será obrigatória e gratuitamente cedida para esse fim. ${ }^{8}$

$\S 4^{\circ}(\ldots)$

Art. 137. Até 10 (dez) dias antes da eleição, pelo menos, comunicarão os juízes eleitorais aos chefes das repartições públicas e aos proprietários, arrendatários ou administradores das propriedades particulares, a resolução de que serão os respectivos edifícios, ou parte deles, utilizados para o funcionamento das mesas receptoras."

Em sua obra Direito eleitoral, ARMANDO ANTONIO SOBREIRO NETO, ${ }^{9}$ eminente promotor de justiça no Estado do Paraná, assim comenta destacadas normas infraconstitucionais:

"As mesas receptoras funcionarão nos lugares designados pelos juízes eleitorais, publicando-se a designação na imprensa oficial, nas capitais, e mediante editais afixados no local de costume, nas demais zonas (CE, art. $135)$.

O Código Eleitoral determina que se deve dar preferência aos edifícios públicos, recorrendo-se aos particulares se faltarem aqueles em número e

8 Semelhante regra foi instituída para a requisição de veículos e embarcações com vistas ao transporte de eleitores, nos termos da Lei ${ }^{\circ} 6.091$, de 15.08.1974 (arts. $1^{\circ}$ e $2^{\circ}$ ).

9 Curitiba: Juruá, 2000, p. 230. 
condições adequados. A propriedade particular será obrigatória e gratuitamente cedida para esse fim (CE, art. $135, \S \S 2^{\circ}$ e $\left.3^{\circ}\right)$."

Também merece referência a seguinte lição de ELCIAS FERREIRA DA $\operatorname{COSTA}^{10}$ sobre referidas normas:

"Os lugares para a votação deverão ser indicados e publicados pelo juiz eleitoral sessenta dias antes da eleição, indicando com clareza o número da seção e o local em que estiver instalada (rua, número e qualquer detalhe que facilite a localização por parte do eleitor). Esses locais deverão ser, preferentemente, edifícios públicos. Será cedida, gratuitamente e obrigatoriamente a propriedade particular (CE, arts. $135, \S \S 1^{\circ}, 2^{\circ}$ e $\left.3^{\circ}\right)$."

Por sua vez, o consagrado jurista FÁVILA RIBEIRO ${ }^{11}$ assim disserta quanto à localização das mesas receptoras de votos:

"A localização das seções constitui assunto a merecer redobrado cuidado da justiça eleitoral (...). O princípio da comodidade do eleitor é de certo modo sacrificado como exigência à liberdade do voto. Com efeito, preconiza a legislação eleitoral a vinculação do eleitor à seção mais próxima de sua residência (...).

Cumpre destacar que as seções podem ser instaladas em prédios particulares. (...) E ao fazê-lo pode requisitar a justiça eleitoral um prédio particular, total ou parcialmente, que deverá ser colocado à disposição gratuitamente. Havendo edifício público em condições, a este deve ser dada preferência. Contudo, se for insuficiente o seu número, deverá haver complementação com prédios particulares.

As escolhas dos locais devem estar efetivadas sessenta dias antes da eleição, acompanhadas da necessária divulgação para conhecimento geral. (...)

Com antecedência mínima de dez dias providenciará o juiz a expedição das requisições de prédios, indicando os espaços que serão ocupados, quando tiver apenas o caráter parcial."

Mister seja também lembrado o posicionamento de JOEL J. CÂNDIDO ${ }^{12}$ sobre a questão, verbis:

"Em uma zona eleitoral, as seções vão sendo organizadas à medida em que vai crescendo o número de deferimentos de pedidos de inscrição. Cria-se uma seção nova com o número de cinqüenta eleitores.

(...) A cada seção eleitoral corresponde uma mesa receptora de votos (CE, art. 119). Os locais de funcionamento dessas mesas são previamente designados 
pelos juízes eleitorais, na forma do art. 135 do Código Eleitoral. 'As seções eleitorais devem ser localizadas dentro do distrito judiciário ou administrativo dos eleitores e o mais próximo deles, considerados a distância e os meios de transporte' (BE-TSE 325/409).

(...) A regra é que é livre a localização das seções, devendo o juiz eleitoral evitar, apenas, os locais proibidos pela lei. (...) Normalmente, as mesas devem funcionar em prédio público, para tal fim previamente requisitado à chefia dos respectivos órgãos. Nada impede que essa requisição seja feita a prédios particulares, sem ônus para a justiça eleitoral (CE, art. $\left.135, \S 3^{\circ}\right)$. O juiz, porém, deve preferir, antes dos prédios residenciais, os de propriedade das pessoas jurídicas, como clubes, sindicatos, associações, colégios, etc.

Hospitais, clínicas, casas de saúde em geral, consultórios de ciência médica ou paramédica, não podem ser requisitados. Nem os templos e prédios destinados a cultos religiosos de profissão lícita no País. Antes deles deve a justiça eleitoral requisitar prédios residenciais. Às demais requisições, todavia, nada se poderá obstar por parte dos proprietários e possuidores, embora casos especialíssimos possam, com antecedência, ser considerados pelo juiz eleitoral que, antes de decidir o pedido de dispensa da cessão, ouvirá de plano o Ministério Público. A recusa infundada a essas requisições ensejará a expedição de mandado de imissão, que deverá ser cumprido nem que seja pelo uso da força, sem prejuízo da apuração da responsabilidade penal do infrator $(\mathrm{CE}$, art. 347)."13

Por fim, invocam-se as observações do citado Professor PAULO AGUIAR DE OLIVEIRA $^{14}$ sobre o tema:

"Ser eleitor, no Brasil, é direito e é dever. (...)

Para realizar a eleição, o direito eleitoral contém uma série de normas, investindo a justiça eleitoral de poderes até mesmo restritivos do direito de propriedade. Assim quando lhe permite requisitar a propriedade particular para instalar seção eleitoral. E requisitar sem ônus.

Para poder alistar eleitores, para realizar um pleito e apurá-lo, tantos outros poderes lhe são deferidos. Por exemplo, requisitar funcionários. (...)

Na eleição, pessoas são designadas para trabalho, sem remuneração. $\mathrm{Na}$ apuração, também. Os empregados, de qualquer natureza, sem prejuízo de seus direitos e vantagens e sem ônus para o Poder Público. E por que isso? Simplesmente porque a eleição constitui um munus, um dever social. Todos devem colaborar e participar, porque os interesses são gerais. Não só o Poder Público, mas toda a comunidade.

13 Código Eleitoral:

"Art. 347. Recusar alguém cumprimento ou obediência a diligências, ordens ou instruções da justiça eleitoral ou opor embaraços à sua execução:

Pena - detenção de três meses a um ano e pagamento de 10 a 20 dias-multa."

14 Op. cit., p. 65. 
O alistamento eleitoral é um dever. Representa um custo direto para a União. Mas existem outros custos que não são considerados. Por exemplo, pode o empregado faltar até dois dias para se alistar, sem prejuízo do salário. É um custo para a empresa. (...)

No preparo de um pleito, existem custos diretos e muitos indiretos. Assim, na propaganda partidária, as empresas de rádio e de televisão devem fornecer horários gratuitos para os partidos e também para as divulgações da justiça eleitoral."

\section{A LEGITIMIDADE DA JUSTIÇA ELEITORAL PARA REQUISITAR IMÓVEIS DE PARTICULARES}

Do até aqui exposto, que se extraiu da doutrina especializada em matéria eleitoral, resulta absolutamente claro que é legítima a requisição de bens imóveis de propriedade particular para os fins colimados no processo eleitoral, a propósito, sem qualquer ônus financeiro para o Poder Público, posto consistir aquela providência em uma das formas legítimas de intervenção do Estado no domínio privado. ${ }^{15}$

A sorte de solução ora apresentada para a questiúncula é de tal modo clara e pacífica que são raros os registros de enfrentamento do tema pela jurisprudência brasileira. Deve-se, porém, ser destacada uma ementa derivada de consulta efetuada ao Tribunal Regional Eleitoral do Rio de Janeiro, que foi assim respondida:

"TRERJ - Processo de Consulta $\mathrm{n}^{\circ}$ 61. Consulta formulada em tese. Parte legítima. Ausência de impedimento legal para a requisição de prédio particular, com vistas ao funcionamento de seção eleitoral, se esgotadas todas as possibilidades de designação de locais de votação."

Também versando sobre a temática, anota-se do Tribunal Regional Eleitoral do Paraná o seguinte aresto relativo ao julgamento, à unanimidade de votos, em sessão de 13.12.2001, do Recurso Eleitoral n ${ }^{\mathrm{o}} 1931$, Classe 2a $2^{\mathrm{a}}$, oriundo da $4^{\mathrm{a}}$ Zona Eleitoral de Curitiba, do qual foi relator o insigne Doutor CÉSAR ANTONIO DA CUNHA:

"Instalação de seções eleitorais. Requisição. Bem particular. Possibilidade. Recurso improvido. Inexistindo edifícios públicos, pode a justiça eleitoral requisitar bens de domínio particular para neles instalar mesas receptoras, nos termos do art. $135, \S \S 2^{\circ}$ e $3^{\circ}$, do Código Eleitoral."

No texto do acórdão relativo a esse julgamento, o nominado relator reportou-se aos seguintes pronunciamentos contidos no parecer do ilustre Procurador Regional Eleitoral, Doutor LUIS SERGIO LANGOWSKI:

15 Na acepção de REIS FRIEDE, “A intervenção do Estado na propriedade (domínio privado) consiste, fundamentalmente, no poder outorgado ao Estado (através de seus atos de império, tendentes a satisfazer as exigências coletivas e a requisitar, limitar o uso, utilizar temporariamente ou mesmo retirar a propriedade particular, em benefício do interesse público relevante." (Curso de direito constitucional e de teoria geral do estado. Rio de Janeiro: Forense, 1999, p. 309) 
“(...) a Constituição Federal de 1988 consagrou e instituiu o Estado Democrático de Direito, fundamentado, entre outros, na soberania, exercida através do sufrágio.

Para que o regime democrático seja assegurado, necessários se fazem alguns sacrifícios, entre eles, da liberdade e da propriedade.

Sendo o voto obrigatório, o Estado deve organizar-se para que as eleições possam ser realizadas, determinando locais adequados para a instalação das seções eleitorais. Assim, são utilizados prédios públicos e, na falta desses, prédios particulares."

Afastando episódica alegação de inconstitucionalidade do citado art. 135 do Código Eleitoral, assentou o relator do aludido recurso, Doutor CÉSAR ANTONIO DA CUNHA, que, "Na verdade, a Constituição Federal reservou à lei complementar dispor sobre organização e competência da justiça eleitoral, com isso recepcionando todas as disposições do Código Eleitoral sobre a matéria (...)", para concluir o relator que, "Portanto, é legítima a requisição, pela justiça eleitoral, para instalação de mesas receptoras, de prédios particulares, que serão cedidos obrigatória e gratuitamente, observado o que dispõe o art. 135 e seus $\S \S 2^{\circ}$ e $3^{\circ}$ do Código Eleitoral”.

\section{A REQUISIÇÃO E AS DEMAIS FORMAS DE INTERVENÇÃO DO ESTADO NO DOMÍNIO PRIVADO}

Evidentemente que a requisição não se confunde com outros institutos jurídicos derivados do poder intervencionista do Estado no domínio privado, como servem de exemplo as aventadas desapropriação, ${ }^{16}$ ocupação temporária ${ }^{17}$ ou servidão administrativa.$^{18}$ A requisição feita pela justiça eleitoral diferencia-se claramente

16 Consoante JOSÉ CRETELLA JÚNIOR, a desapropriação "Stricto sensu, é a operação complexa de direito público mediante a qual a Administração obriga o proprietário de um bem a transferir-lhe a propriedade e posse desse bem, mediante prévia e justa indenização em dinheiro, desde que haja necessidade pública ou interesse social" (Dicionário de direito administrativo. 5. ed. Rio de Janeiro: Forense, 1999, p. 144).

17 Para JOSÉ CRETELLA JÚNIOR, a ocupação temporária é "Utilização por parte do Estado da propriedade particular, com ou sem indenização durante tempo limitado, por motivos de utilidade pública, necessidade pública ou interesse social. Imposição da Administração ao particular, para que ceda seu terreno a fim de que aí sejam depositados materiais, ferramentas ou para dali se extraírem materiais necessários ao trabalho. (...) O instituto da ocupação temporária assume duas modalidades principais, uma para a construção de obras públicas, outra para operações de urgência. No primeiro caso, incluem-se maquinaria, enfim, tudo de que necessitam os empreiteiros para executar a obra pública requerida. Neste caso, a ocupação se justifica pela necessidade de retirar-se matéria-prima do terreno, como pedras, areia, saibros, pedregulho. No segundo caso, há necessidade de urgência, mais do que a genérica, e, às vezes, inadiável utilidade pública, a justificar a ocupação de casas ou terrenos particulares, como, por exemplo, em caso de incêndio, de inundação ou de interdição de prédio que ameaça ruir ou, ainda, nos casos de isolamento para evitar a propagação de moléstias contagiosas" (op. cit., p. 318).

18 Segundo MARCELO CAETANO, a servidão administrativa é "Direito público real constituído por pessoa jurídica de direito público sobre imóvel no domínio privado para que este, como prolongamento 
daquelas outras formas de intervenção do Estado sobre a propriedade particular, ${ }^{19}$ notadamente porque a utilização das dependências requisitadas ficará restrita ao período eleitoral, via de regra, a véspera e o dia das eleições, e não se constitui de procedimento expropriatório, daí por que não se cogita de prévia e justa indenização em dinheiro.

Tampouco não se confunde a requisição com a locação ${ }^{20}$ ou outra forma de contrato que, como tal, implique ajuste prévio entre a justiça eleitoral e o particular de quem se requisita o imóvel. É que, como se destacou, a requisição é medida unilateral e auto-executória, ou seja, efetiva-se independentemente da vontade do particular e não comporta pagamento de preço pelo uso do bem requisitado.

As assertivas acima delineadas correspondem ao que nos ensina a mais abalizada doutrina brasileira, não só pelo que se sublinhou anteriormente, como também pelo que se aventará a seguir. Veja-se.

HELY LOPES MEIRELLES, ${ }^{21}$ com a maestria que o consagrou, pronunciou-se sobre a requisição nos seguintes termos:

"Requisição é a utilização coletiva de bens ou serviços particulares pelo Poder Público, por ato de execução imediata e direta da autoridade requisitante e indenização ulterior, para atendimento de necessidades coletivas urgentes e transitórias. O fundamento do instituto da requisição encontra-se no art. 153, $\S 22$, da Constituição da República, que autoriza o uso da propriedade particular, na iminência de perigo público, pelas autoridades competentes (civis ou militares).

A requisição tem origens bélicas, mas se transformou em instrumento civil, ou mais propriamente, administrativo, como meio de intervenção estatal na propriedade particular."

Por sua vez, MARIA SYLVIA ZANELLA DI PIETRO ${ }^{22}$ assim disserta sobre a requisição:

do domínio público, possa atender os interesses coletivos. Entre os vários tipos de servidões administrativas podemos citar as seguintes: servidões de aquedutos, servidões de atravessadores, servidões nas linhas telegráficas e telefônica, servidões aéreas, servidões de faróis, servidões militares, servidões dos monumentos históricos e muitas outras. (...) Só dão lugar a indenização mediante lei expressa, podendo ser negativas ou positivas, impostas ou definidas por processos enérgicos revestidos de coação, inalienáveis, imprescritíveis, cessando com a desafetação dos bens dominiais ou com o desaparecimento da função pública das coisas dominantes" (cf. CRETELLA JÚNIOR, José. Op. cit., p. 436).

19 Dentre essas modalidades de intervenção estatal no domínio privado há que ser referido, ainda, o tombamento, que como se sabe, decorre do poder de polícia do Estado e importa em restrições parciais ao direito de propriedade, não indenizáveis, com vistas à proteção do patrimônio histórico, artístico e cultural da nação.

20 Na definição de DE PLÁCIDO E SILVA, locação deriva-se "do latim locatio, de locare (dispor, situar, estabelecer), originariamente quer exprimir a colocação de uma coisa à disposição de alguém, mediante um preço" (In: Vocabulário jurídico. Rio de Janeiro: Forense, v. III, 1982, p. 111).

21 Direito administrativo brasileiro. São Paulo: Revista dos Tribunais, 1985, p. 527.

22 Direito administrativo. São Paulo: Atlas, 2001, p. 129. 
"A requisição administrativa pode apresentar-se sob diferentes modalidades, incidindo ora sobre bens, móveis ou imóveis, ora sobre serviços, identificandose, às vezes, com a ocupação temporária e assemelhando-se, em outras, à desapropriação; é forma de limitação à propriedade privada e de intervenção estatal no domínio econômico; justifica-se em tempo de paz e de guerra. (...)

Em qualquer das modalidades, a requisição caracteriza-se por ser procedimento unilateral e auto-executório, pois independe da aquiescência do particular e da prévia intervenção do Poder Judiciário."

MELO: ${ }^{23}$

Ainda sobre a requisição, eis o que ensina CELSO ANTONIO BANDEIRA DE

"Requisição é ato pelo qual o Estado, em proveito de um interesse público, constitui alguém, de modo unilateral e auto-executório, na obrigação de prestarlhe um serviço ou ceder-lhe transitoriamente o uso de uma coisa in natura, obrigando-se a indenizar os prejuízos que tal medida efetivamente acarretar ao obrigado.

A requisição funda-se no art. $5^{\circ}, \mathrm{XXV}$, do Texto Constitucional brasileiro, e a competência para legislar sobre ela assiste apenas à União, conforme o art. 22, III, da Constituição."

E, a seu turno, eis o que leciona DIÓGENES GASPARINI:24

"Requisição. Em situação de urgência, ou não, e quase sempre sem o caráter de definitividade, a Administração Pública, com ou sem indenização posterior, pode utilizar bens particulares, valendo-se de atos e medidas auto-executórias, cuja obtenção, pelos procedimentos comuns, porque demorados ou dependentes da vontade do particular, prejudicaria a eficiência administrativa. É a requisição. Pode ser definida como a utilização, quase sempre transitória, pela Administração Pública, de bens particulares, mediante determinação da autoridade competente, com ou sem indenização posterior, em razão ou não de perigo público.

Seu fundamento político é o estado de necessidade pública. Tem, entre nós, dois fundamentos constitucionais. Um, genérico, previsto no inciso III do art. 170 (função social da propriedade); outro, específico, fincado no inciso XXV do art. $5^{\circ}$, embora essa disposição pareça sempre exigir uma situação de urgência, de perigo público. Tal utilização, como ato ou medida auto-executória que é, independe de prévia autorização judicial. Os abusos, no entanto, podem ser obstados por mandado de segurança. Seu controle é, por conseguinte, $a$ posteriori.

Pode recair, como vimos, sobre bens móveis, imóveis e semoventes. Se incidir sobre bens consumíveis (gêneros alimentícios, roupas, cobertores) é definitiva. Nesse caso, há transferência dominial e a correspondente indenização posterior, sem, no entanto, caracterizar uma desapropriação. Da desapropriação difere porque a indenização é a posteriori, isto é, não é prévia como exige a 
Constituição para a expropriação, e porque independe, para a sua concreção, do auxílio do Judiciário, mesmo quando for contrária aos interesses de seu proprietário. Se recair sobre bens inconsumíveis (terrenos, prédios, máquinas, veículos), é transitória. Finda, nesse caso, a utilização, devolve-se o bem ao proprietário e se satisfaz, de modo completo, o prejuízo causado.

As requisições podem ser civis e militares. (...) As civis, não por favorecerem os particulares, mas por prestigiarem as autoridades públicas, são também chamadas de administrativas e se destinam a evitar um dano à vida, à saúde e aos bens da coletividade ou a minorar os seus efeitos, ou, ainda, a facilitar a prestação de certo serviço público."

Por fim, cumpre-se trazer à colação as considerações de JOSÉ CRETELLA JÚNIOR ${ }^{25}$ sobre a requisição:

"Operação unilateral de gestão pública pela qual a Administração exige de uma pessoa a prestação de atividade, o fornecimento de objetos móveis, o abandono temporário de gozo de imóveis ou de empresas, para usá-los conforme o interesse geral, num determinado fim (DUEZ e DEBEYRE, Traité... 1952, p. 859). (...) $\mathrm{O}$ instituto da requisição, que se apóia no sacrifício privado em prol do interesse público, apresenta-se, na prática, como o procedimento unilateral da Administração, obrigando o sujeito particular à prestação de serviços ou à entrega de bens, dirigidos à satisfação de interesses coletivos."

\section{REQUISIÇÃO DE BENS PELA JUSTIÇA ELEITORAL: UM DIREITO CONSTITUCIONALMENTE ASSEGURADO}

Como ficou demonstrado, o instituto da requisição encontra pleno amparo na vigente Carta Constitucional, notadamente o art. $5^{\circ}$, inciso $\mathrm{XXV},{ }^{26}$ a exemplo do que já ocorria em relação ao texto constitucional anterior, não havendo, pois, que se cogitar de sua inconstitucionalidade.

Comentando o inciso XXV do art. $5^{\circ}$ da Carta Constitucional, CELSO RIBEIRO BASTOS e IVES GANDRA MARTINS ${ }^{27}$ assim sustentam:

"A via da desapropriação não satisfaz a todas as necessidades do Poder Público em matéria de bens. Isto porque, pelas suas próprias características, aquele instituto é moroso, ao menos relativamente à necessidade de atender a situações de urgência. (...) É fácil imaginar que o Estado, não raras vezes, tem

25 Op. cit., p. 395.

26 Constituição Federal:

"Art. $5^{\circ}$ Todos são iguais perante a lei, sem distinção de qualquer natureza, garantindo-se aos brasileiros e aos estrangeiros residentes no País a inviolabilidade do direito à vida, à liberdade, à igualdade, à segurança e à propriedade, nos seguintes termos:

(...)

XXV - no caso de iminente perigo público, a autoridade competente poderá usar de propriedade particular, assegurada ao proprietário indenização ulterior, se houver dano."

27 Comentários à Constituição do Brasil (promulgada em 5 de outubro de 1988). São Paulo:

Saraiva, 1989, p. 136-138. 
de enfrentar situações emergenciais para as quais torna-se indispensável a utilização de bens, tanto móveis quanto imóveis, que não poderiam sujeitar-se às delongas de um processo expropriatório.

Daí por que a Constituição prevê a possibilidade de uso de bem particular independentemente da vontade do seu titular que restringe uma das prerrogativas do domínio, qual seja: o direito das medidas que criam ressalvas à proteção constitucional da propriedade privada. (...)

No entanto, a expressão 'perigo público iminente' é bastante em si mesma para transmitir a idéia que deseja. Trata-se de atender a situações de calamidade pública ou mesmo de convulsão ou perturbação social, que não permitam o funcionamento normal das atividades e serviços corriqueiramente prestados. Tal situação faz pesar sobre os ombros das autoridades o dever de assegurar o funcionamento daqueles serviços sem os quais a coletividade entraria em colapso.

É fácil notar que não se exige que o perigo esteja em fase inicial de consumação. Basta que ele seja iminente, é dizer: impõe-se a existência de uma ameaça próxima. (...)

Portanto, embora matéria de apreciação discricionária dos Poderes Públicos que haverão de aquilatar com serenidade e moderação se em determinado caso configura-se ou não perigo público iminente, o certo é que do seu possível abuso caberá recurso ao Poder Judiciário. (...)

Finalmente, há que se mencionar o requisito da indenização. Esta imporse-á por ditame constitucional toda vez que houver dano. Este pode assumir múltiplas formas. O próprio bem utilizado pode ter sofrido avarias, ou seu proprietário pode ter sofrido prejuízo pela privação temporária do bem. De qualquer sorte, ao particular cabe a comprovação do dano sofrido, não sendo suficiente a mera presunção. Não há, pois, o dever de as autoridades públicas pagarem pela simples utilização do bem, mas tão-somente pelo dano que eventualmente o seu proprietário tiver sofrido, o que será feito a posteriori."

Como, pois, claramente elucidado pelos insignes constitucionalistas citados, as requisições de bens de particulares pela justiça eleitoral, para a efetivação do processo eleitoral, enquadram-se perfeitamente à previsão do inciso XXV do art. $5^{\circ}$ da Carta Maior conquanto, como é curial, aquelas providências somente são adotadas em casos de absoluta necessidade e urgência, ante o risco de iminente colapso na prestação dos imprescindíveis serviços públicos eleitorais, e assegurando-se aos proprietários dos bens requisitados a correspondente indenização por danos que eventualmente venham a se verificar em face do uso da propriedade pela autoridade requisitante. ${ }^{28}$

28 E sem olvidar a advertência de JOÃO CARLOS ADALBERTO ZOLANDECK que, ao referir-se à política intervencionista do Estado, ressalta que "A intervenção legítima terá, portanto, por base o interesse público e por limite os direitos fundamentais assegurados na Constituição" (Intervenção democrática do Estado nos domínios econômico, social e cultural. Argumenta: Revista do Curso de Mestrado em Ciência Jurídica da FUNDINOPI - Faculdade de Direito do Norte Pioneiro, v. 1, n. 1, p. 257, Jacarezinho, 2001). 


\section{O CONFRONTO ENTRE O DIREITO ESTATAL DE REQUISITAR E O DIREITO DE PROPRIEDADE, AMBOS ASSEGURADOS CONSTITUCIONALMENTE}

Também se extrai da doutrina supradestacada e da que adiante ainda invocarse-á, que o direito de propriedade que possa ser clamado pelo particular, com fundamento no art. $5^{\circ}$, XXII, da Constituição Federal, é um direito relativo. Veja-se.

Para JOSÉ CARLOS CAL GARCIA 29 "A propriedade privada é assegurada e protegida pelo Estado, diz a Constituição. Mas é subordinado o seu exercício ao bemestar social, à conservação dos recursos naturais e à proteção do meio ambiente. No fundo, é a função social da propriedade que deve servir de parâmetro para o exercício do direito de propriedade".

MARIA SYLVIAZANELLA DI PIETRO ${ }^{30}$ manifesta-se no mesmo sentido de CAL GARCIA ao enunciar que "Na Constituição de 1988, o art. $5^{\circ}$, inciso XXII, garante o direito da propriedade, mas no inciso XXIII determina que a propriedade atenderá à sua função social; além disso, ela volta a ser incluída entre os princípios da ordem econômica, que têm por fim 'assegurar a todos existência digna, conforme os ditames da justiça social' (art. 170, III)".

MARIA SYLVIA ZANELLA DI PIETRO ${ }^{31}$ ainda assenta em suas anotações o seguinte:

"A Constituição de 1967 incluiu a função social da propriedade como um dos princípios da ordem econômica e social (art. 160, III), que coexiste com o da propriedade como direito individual consagrado no art. 153, §22. Segundo MANOEL GONÇALVES FERREIRA FILHO (1975, v. 3:166), 'isto significa que a propriedade não é a da concepção absoluta romanística, e sim a propriedade encarada como uma função eminentemente social. É o que se depreende do texto do art. 160, III, que implicitamente condena a concepção absoluta da propriedade, segundo a qual esta é o direito de usar gozar e tirar proveito de uma coisa de modo puramente egoístico, sem levar em conta o interesse alheio e particularmente o da sociedade. Reconhecendo a função social da propriedade, a Constituição não nega o direito exclusivo do dono sobre a coisa, mas exige que o seu uso seja condicionado ao bem-estar geral. Não ficou, portanto, o constituinte longe da concepção tomista, segundo a qual o proprietário é um procurador da comunidade para a gestão de bens destinados a servir a todos, embora pertençam a um só.".

Por fim, não há que se olvidar que, segundo as conclusões de JUAREZ FREITAS ${ }^{32}$ assinaladas em seu valioso artigo "O intérprete e o poder de dar vida à Constituição":

29 Linhas mestras da Constituição de 1988. São Paulo: Saraiva, 1989, p. 19.

30 Op. cit., p. 122.

31 Op. cit., loc. cit.

32 Revista da Faculdade de Direito da Universidade Federal do Paraná, Porto Alegre: Síntese, v. 34, p. 
“(d) o intérprete constitucional deve ser o guardião, por excelência, de uma visão proporcional dos elementos constitutivos da Carta Maior, não entendida a proporcionalidade apenas como adequação meio-fim. Proporcionalidade significa, sobremodo, que estamos obrigados a sacrificar o mínimo e preservar o máximo de direitos."

E ainda:

“(f) o intérprete constitucional deve guardar vínculo com a excelência ou otimização máxima da efetividade do discurso normativo da Carta, no que esta possui de eticamente superior, conferindo-lhe, assim, a devida coerência interna e não menos devida eficácia social."

\section{CONCLUSÃO}

Posto isso e finalizando esse despretensioso artigo, convocam-se as avaliações de PAULO AGUIAR DE OLIVEIRA, ${ }^{33}$ adiante transcritas, as quais, com incomparável maestria, sintetizam o presente manifesto:

"Contém o Código Eleitoral norma clara e induvidosa sobre a obrigatoriedade da cessão gratuita da propriedade particular para fim de localização de mesa receptora de votos. Essa determinação tem sido questionada, fulminada de inconstitucionalidade, por atingir o direito de propriedade, restringindo-o. (...) Efetivamente, a Constituição assegura o direito de propriedade e é expresso quanto às restrições, inclusive a faculdade de desapropriação. Mas, por outro lado, a propriedade tem sentido social. A eleição é ato do mais puro sentido social, de interesse da coletividade, de toda a comunidade. Sua realização se opera pela comunidade inteira. Eleitores são seus membros. São estes decidindo sobre quais se incumbirão da representação ou da direção comunitária. A constituição das mesas coletoras de votos, como a constituição das juntas eleitorais, é feita entre os próprios membros da sociedade. Enfim, é o povo que vota, que dirige a votação e que apura a manifestação de vontade. Esse o sentido e o significado das normas legais, erigindo os encarregados em certa parcela de poder.

Não teria o Estado a condição de manter prédios públicos exclusivamente para esse fim, e nem aqueles de uso dos serviços públicos seriam suficientes. Por essa razão, o legislador obriga a cessão gratuita da propriedade particular para esse fim. É um ônus ao direito de propriedade, justificado pela relevância. Não se diria inconstitucional, pois que, virtualmente, estaria assegurada a permissão ao comportamento do legislador. $\mathrm{O}$ ato é, pois, legítimo.

A gratuidade da utilização pública da propriedade particular, porém, não afastará o dever de o Estado indenizar danos, eventualmente, causados à propriedade. Não importa sejam os danos causados por integrantes das mesas receptoras do voto, ou mesmo pelos votantes, ou terceiros. Desde o instante em que haja a requisição, o dever de conservar a coisa passa à responsabilidade do Estado. 
A cessão do imóvel há de ser em condição de servir ao uso que, legitimamente, se pretende, e nessa mesma condição deve ser restituído. Por isso mesmo, qualquer ato que resulte em danificação da propriedade é passível de caracterizar a responsabilidade, independente de se apurar a culpa do agente."

Não é demasiado anotar que em todo o território nacional são costumeira e historicamente requisitados imóveis de particulares para utilização na véspera e no dia das eleições, designadamente as instalações de instituições privadas de ensino. Assim sendo, se admitida uma injustificada recusa de algum proprietário de imóvel particular em cedê-lo para utilização pela justiça eleitoral, tal concessão pode se caracterizar em tratamento privilegiado, ou seja, ofensivo ao tão precioso princípio da isonomia gizado no art. $5^{\circ}$, caput, da Constituição Federal e, demais disso, poderia se constituir em temerário precedente, posto que capaz de comprometer todo o sistema eleitoral brasileiro. Reafirma-se, pois, a proposição preambular.

\section{REFERÊNCIAS BIBLIOGRÁFICAS}

BASTOS, Celso Ribeiro; MARTINS, Ives Gandra. Comentários à Constituição do Brasil (promulgada em 5 de outubro de 1988). São Paulo: Saraiva, 1989.

CÂNDIDO, Joel J. Direito eleitoral brasileiro. Bauru: EDIPRO, 2000.

COSTA, Elcias Ferreira da. Compêndio de direito eleitoral. São Paulo: Sugestões Literárias, 1978.

CRETELLA JÚNIOR, José. Dicionário de direito administrativo. Rio de Janeiro: Forense, 1999.

DI PIETRO, Maria Sylvia Zanella. Direito administrativo. São Paulo: Atlas, 2001.

FREITAS, Juarez. O intérprete e o poder de dar vida à Constituição. Revista da Faculdade de Direito da Universidade Federal do Paraná, Porto Alegre: Síntese, v. 34, 2000.

FRIEDE, Reis. Curso de direito constitucional e de teoria geral do estado. Rio de Janeiro: Forense, 1999.

GARCIA, José Carlos Cal. Linhas mestras da Constituição de 1988. São Paulo: Saraiva, 1989. GASPARINI, Diógenes. Direito administrativo. São Paulo: Saraiva, 2000.

MEIRELLES, Hely Lopes. Direito administrativo brasileiro. São Paulo: Revista dos Tribunais, 1985.

MELO, Celso Antonio Bandeira de. Curso de direito administrativo. São Paulo: Malheiros, 2001.

OLIVEIRA, Paulo Aguiar de. Responsabilidade do estado por atos da justiça eleitoral. Revista de Direito Público, São Paulo: Revista dos Tribunais, v. 20, n. 83, jul./set. 1987.

RIBEIRO, Fávila. Direito eleitoral. Rio de Janeiro: Forense, 1988.

SILVA, De Plácido e. Vocabulário jurídico. Rio de Janeiro: Forense, v. III, 1982.

SOBREIRO NETO, Armando Antonio. Direito eleitoral. Curitiba: Juruá, 2000.

ZOLANDECK, João Carlos Adalberto. Intervenção democrática do Estado nos domínios econômico, social e cultural. Argumenta: Revista do Curso de Mestrado em Ciência Jurídica da FUNDINOPI - Faculdade Estadual de Direito do Norte Pioneiro, v. 1, n. 1, Jacarezinho, 2001. 